\title{
Evaluation on Safety Benefits of Mining Industry Occupational Health and Safety Management System Based on DEA Model and Grey Relational Analysis
}

\author{
Jiangdong Bao, Jan Johansson, and Jingdong Zhang
}

\begin{abstract}
The mining industry safety production situation is becoming more and more severe in China with safety accidents occurring frequently, which is closely related to insufficient safety investments and unreasonable distribution. Additionally, it does not keep in line with the main purpose of occupation health and safety management system (OHSAS18001).In order to carry on the reasonable scientific disposition to the safety investments of the mining industry, increase safety investments efficiency and satisfy the requirements of OHSAS18001, data envelopment analysis (DEA) is adopted to calculate the safety investments, loss and output. Firstly, the analysis software MYDEA of DEA is used to calculate the results to obtain the evaluation result of safety benefits. Secondly, the target value of the improvement work in the aspect of investment is achieved by method of projection analysis when the decision making unit $\left(\mathrm{DMU}_{\mathrm{j} 0}\right)$ of non DEA efficiency is changed into DEA efficiency. Lastly, it can be obtained on the basis of grey relational analysis (GM) that the investment amount of safety management and training of employees has the highest relation on the effective safety benefits of the mining industry. Thus, the investment of safety management and training of employees should be strengthened. This kind of empirical method of comprehensive model provides a direction and theoretical reference for safety investments benefits analysis and optimized investment structure, and a structure for the effective operation of mining industry occupational health and safety management system.
\end{abstract}

Index Terms-Mining industry, OHSAS18001, safety benefits, DEA, grey relational analysis.

\section{INTRODUCTION}

OHSAS18001 is an effective way which is recognized by the international organization and proved effective to the occupational health and safety management of the employees. It has put forward the PDCA requirement of system operation planning, personnel management, operational control and so on. Although it has introduced into mining industry for many years, the safety accidents occurring frequently result in great economic loss and passive safety

Manuscript received December 7, 2016; revised May 1, 2017.

Jiangdong Bao and Jan Johansson are with Centre of Advanced Mining and Metallurgy, CAMM, Department of Human Work Science, Luleå University of Technology, Luleå 97751, Sweden (e-mail: bao.jiangdong@1tu.se; Jan.Johansson@1tu.se).

Jingdong Zhang is with Research Center for Environment and Health, Zhongnan University of Economics and Law, Wuhan, 430000, China (corresponding author: Jingdong Zhang ; e-mail: 17099337648@163.com). investments which are contrary to the purpose of continuous improvement of OHSAS18001. Feasible DEA model and grey relational analysis method used in this paper supply a reasonable distribution basis for mining industry OHSAS18001. Additionally, the methods provide strong support for the healthy and sustainable development of OHSAS18001.

\section{SAFETY INVESTMENTS AND BENEFITS INDICATORS OF MINING INDUSTRY OHSAS18001}

According to the OHSAS18001standard requirements [1] of 4.4.1 Resources, roles, responsibility, accountability and authority, 4.4.2 Competence, training and awareness, 4.4.6 Operational control, 4.4.7 Emergency preparedness and response and 4.5.1 Performance measurement and monitoring. Additionally, requirements of actual operation of mining industry, four safety investment indicators of mining OHSAS18001are established as shown in the following: safety technical measures, industrial hygiene measures, safety management and training and labor protection products [2].

\section{A. Safety Benefits}

Safety benefits refer to realization of safety level, the benefits to the society, the community and the individual [3]. Additionally, they are composed of the sum (decrease loss output and increment output) - total safety investments ratio [4].

\section{B. Safety Technical Measures}

Safety technical measures refer to preventing casualty accidents including ventilation system, protection device, insurance device, signal device etc.

\section{Industrial Hygiene Measures}

Industrial hygiene measures are the technical measures of improving the production environment which do harm to the health of workers and preventing occupational diseases and poisoning, including anti-virus, dust, anti vibration and noise, ventilation, cooling, cold and other equipments etc.

\section{Safety Management and Training}

Safety management and training cover technical services, training, hardware and software equipments, occupation health examination of employees, three levels of safety education, all kinds of emergency supplies etc. 


\section{E. Labor Protection Products}

Labor protection products are the necessary equipments and all labor hygiene protection measures including disinfection room, changing room or clothing room, shower room, women's health room etc.

\section{F. Decrease Loss Output}

Decrease loss output means that safety investments activities guarantee the safety production of enterprises, reduce or avoid some safety accidents, reduce the damage to the human society and the environment caused by the accident, protect the wealth of social enterprise effectively and reduce the waste of resources.

\section{G. Increment Output}

Increment output is also the increment benefit of safety which means that the benefits are produced by guaranteeing the working conditions of the workers and maintaining the increment process of the enterprise economics.

\section{SAFETY BENEFITS OF MINING INDUSTRY OHSAS18001 BASED ON DEA MODEL}

Data envelopment analysis (DEA) was first introduced by famous operational research experts: A. Charnes, W.W. Cooper and E. Rhodes in 1978 [5]-[6]. It was used to evaluate the relative effectiveness of the same department whose first model was called $\mathrm{C}^{2} \mathrm{R}$ model. From the point of view of production function, it is a very good and effective way to study several inputs especially when "production department" are "effective scale" and "technical efficiency" at the same time.

\section{A. The $i^{\text {th }}$ Input and the $r^{\text {th }}$ Output}

The $i^{\text {th }}$ input of unit $j$ is explained by $x_{i j}$, the $r^{\text {th }}$ output of unit $j$ is explained by $y_{r j}$ and the input and output is shown as follows:

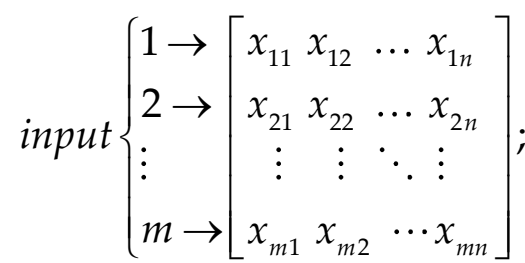

$$
\begin{aligned}
& \left.\left[\begin{array}{cccc}
y_{11} & y_{12} & \cdots & y_{1 n} \\
y_{21} & y_{22} & \cdots & y_{2 n} \\
\vdots & \vdots & \ddots & \vdots \\
y_{s 1} & y_{s 2} & \cdots & y_{s n}
\end{array}\right] \rightarrow \begin{array}{l}
1 \\
\vdots \\
\vdots
\end{array}\right\} \text { output }
\end{aligned}
$$

\section{B. The Formula $h_{j}$ of Input-Output Ratio}

Suppose the weight of $i^{t h}$ input is expressed by $v_{i}$ and the weight of $r^{\text {th }}$ output is expressed by $u_{i}$. Let $v_{i}(i=1,2, \ldots m), u_{i}$ $(r=1,2, \ldots s), j=1,2, \ldots n$ and $h_{j} \leq 1$. Then the optimization model of formula $h_{j}$ of input-output ratio of $j^{\text {th }}$ decision making unit and performance appraisal of $j_{0}$ each decision making unit can be summed up as follows:

$$
\begin{gathered}
j=\frac{\sum_{r=1}^{s} u_{r} y_{r j}}{\sum_{i=1}^{m} v_{i} x_{i j}}(j=1,2, \ldots n) ; \\
\max h_{j 0}=\frac{\sum_{r=1}^{s} u_{r} y_{r j 0}}{\sum_{i=1}^{m} v_{i} x_{i j 0}} ; \\
\text { s.t }=\left\{\begin{array}{l}
\frac{p}{\sum_{r=1}^{m} u_{r} y_{r j}} \leq 1, j=1,2, \ldots n \\
\sum_{i=1}^{m} v_{i} x_{i j} \\
v_{i}, u_{r} \geq 0, i=1,2, \ldots m ; r=1,2, \ldots p
\end{array}\right.
\end{gathered}
$$

\section{The Transformation of the Fractional Programming Problem}

This is a fractional programming problem, which can be transformed into an equivalent linear programming problem as shown below:

$$
t=\frac{1}{\sum_{i=1}^{m} v_{i} x_{i j 0}} \mu_{r}=t u_{r} w_{i}=t v_{i}
$$

\section{The Linear Programming Model and Vector Form}

The linear programming model and vector form are shown as follows:

$$
\begin{aligned}
& \max _{j 0}=\mu^{T} Y_{0} \\
& \text { s.t }=\left\{\begin{array}{l}
\mu^{T} Y_{j}-\omega^{T} X_{j} \leq 0 \\
\omega^{T} X_{0}=1 \\
\omega \geq 0, \mu \geq 0
\end{array}\right.
\end{aligned}
$$

$$
\begin{aligned}
& \max h_{j 0}=\sum_{r=1}^{p} u_{i} Y_{r j 0} \\
& \text { s.t. }\left\{\begin{array}{l}
\sum_{r=1}^{p} u_{i} Y_{r j}-\sum_{i=1}^{m} w_{i} X_{i j} \leq 0, j=1,2, \ldots n \\
\sum_{i=1}^{m} w_{i} X_{i j 0}=1 \\
w_{i} \geq 0, u_{i} \geq 0, i=1,2, \ldots m ; r=1,2, \ldots p
\end{array}\right.
\end{aligned}
$$

\section{E. The Dual Problem and Vector Form}

The dual problem and vector form are shown as follows:

$$
\begin{aligned}
& \min v_{D}=\theta \\
& \text { s.t. }\left\{\begin{array}{l}
\sum_{j=1}^{n} \lambda_{j} x_{i j} \leq \theta x_{i 0}, i=1,2, \ldots m \\
\sum_{j=1}^{n} \lambda_{j} y_{r j} \geq y_{r 0}, r=1,2, \ldots p \\
\lambda_{j} \geq 0, \theta \in \text { unconstrained }
\end{array}\right.
\end{aligned}
$$




\section{$D M U \min \theta$}

$$
\text { s.t. }\left\{\begin{array}{l}
\sum_{j=1}^{n} \lambda_{j} x_{j}+s^{-}=\theta x_{0} \\
\sum_{j=1}^{n} \lambda_{j} y_{j}-s^{+}=y_{0} \\
s^{-} \geq 0, s^{+} \geq 0, \lambda_{j} \geq 0
\end{array}\right.
$$

\section{F. Theorem 1 of Relative Efficiency Evaluation of $C^{2} R$ Model}

Relative efficiency evaluation of $C^{2} R$ model: (1) Suppose $\theta=1, s_{0}{ }^{-}=1, s_{0}{ }^{+}=0$, the decision making unit $j$ is called DEA efficiency. (2) Suppose $\theta<1, s_{0}{ }^{-} \neq 0, s_{0}{ }^{+} \neq 0$, the decision making unit $j_{0}$ is called non DEA efficiency.

\section{GREY RELATIONAL ANALYSIS OF SAFETY INVESTMENTS AND BENEFITS OF MINING INDUSTRY OHSAS18001}

The grey system theory was created by Chinese Professor Deng Julong in 1880s [7]. The grey system theory has been successfully introduced to agricultural, industrial, economic and other science fields for over 20 years. Grey system is not fully known with information, that is, some information is known and some other is unknown. Grey relational analysis is an important part of grey system theory whose method is used to analyze the correlation degree of each factor of the system, to calculate the grey relation between the system characteristic variables and the variables of the data sequence and to analyze the advantages results and the evaluation results [8]-[10].

At present, the calculation model about the grey relation between the sequences is the following [11]. Deng Relational Analysis [12], Grey Euclid Relation Grade [13], Absolute correlation degree [14], Generalized Degree of Grey Incidence [15], T's correlation Degree [16], C-Mode Relational Analysis [17], B-Mode Relational Analysis [18]. The method of Deng Relational analysis method is utilized in this paper.

\section{A. Determining the Analysis Sequence}

Select reference series and let $X=\left\{x_{0}, x_{1}, \cdots, x_{m}\right\}$ be grey relation factor set, $x_{0}$ be a reference sequence, $x_{i}$ be a comparison sequence, and $x_{0}(k), \quad i=\{1,2, \cdots, m\}$ $x_{i}(k)$ be the $k$ point number of $x_{0}$ and $x_{i}$ as shown below:

$$
\begin{aligned}
& x_{0}=\left(x_{0}(1), x_{2}(2), \cdots, x_{0}(n)\right) ; x_{1}=\left(x_{1}(1), x_{1}(2), \cdots, x_{1}(n)\right) \\
& x_{2}=\left(x_{2}(1), x_{2}(2), \cdots, x_{2}(n)\right) \cdots \cdots, \\
& x_{m}=\left(x_{m}(1), x_{m}(2), \cdots, x_{m}(n)\right)
\end{aligned}
$$

\section{B. Non Dimensional Variables}

Each factor in the data of the column may be different because of the dimension, so it is hard to get the correct conclusion when in comparison. The data is generally performed by non dimensional treatment during the grey relational analysis:

$$
x_{i}(k)=\frac{x_{i}(k)}{x_{i}(1)}, \mathrm{k}=1,2, \ldots \mathrm{n} ; \mathrm{i}=1,2, \ldots \mathrm{m}
$$

\section{Calculating the Relational Coefficient}

The relational coefficient of $x_{0}(k)$ and $x_{i}(k)$ is shown below:

$$
\begin{gathered}
\zeta_{i}(k)=\frac{\min _{i} \min _{k}\left|X_{0}(k)-X_{i}(k)\right|+\rho \max _{i} \max _{k}\left|X_{0}(k)-X_{i}(k)\right|}{\left|X_{0}(k)-X_{i}(k)\right|+\rho \max _{i} \max _{k}\left|X_{0}(k)-X_{i}(k)\right|} \\
r\left(x_{0}(k), x_{i}(k)\right)=\frac{\Delta_{\min }+\rho \Delta_{\max }}{\Delta_{0 i}(k)+\rho \Delta_{\max }}
\end{gathered}
$$

In the formula, $\Delta_{0 i}(k)=\left|x_{0}(k)-x_{i}(k)\right|$ is the absolute difference,

$$
\Delta_{\min }=\min _{i} \min _{k} \Delta_{0 i}(k)
$$

is the minimum

$$
\Delta_{\max }=\max _{i} \max _{k} \Delta_{0 i}(k) \text { is }
$$

the maximum difference between two poles, $\rho$ is the resolution ratio, $\rho \in(0,1)$ (remarks: $\rho$ value normally equals 0.5 in actual calculation.), and $\omega^{k}$ is the weight of $k$

point number which satisfies

$$
0 \leq \omega_{k} \leq 1, \sum_{k=1}^{n} \omega_{k}=1 \text {. }
$$

\section{Calculating Grey Relation}

Because the relational coefficient is too scattered to compare overall, normally the average value is expressed as the degree value between comparison sequence and reference sequence, and $r_{i}$ formula of the relational coefficient is as follows [19]:

$$
r_{i}=\frac{1}{n} \sum_{k=1}^{n} \zeta_{i}(k)
$$

\section{E. The Relation Ranking}

Normally, if $r\left(x_{0}, x_{i}\right)>r\left(x_{0}, x_{j}\right)$, the relation of $x_{i}$ and $x_{0}$ is higher than that of $x_{j}$ and $x_{0}$. That is to say, the Influence degree of $x_{i}$ on $x_{0}$ is higher than that of $x_{j}$ on $x_{0}$.

\section{CASE Study}

The mining lies in the Southwest of the Hubei Province, China with nice mining resources. OHSAS18001 has been one of the management methods for many years with a good 
reputation in the local community as well as the society. Taking the mining industry as an example, this paper evaluates the effective safety investments and safety benefits by methods of DEA and grey relational analysis.

\section{A. Safety Investments and Loss Statistics}

As shown in Table 1, the 4 first-grade indicators of the mining industry safety investments including safety technical measures etc. and 23 second-grade indicators including ventilation system etc. are chosen to analyze. Statistical information of safety investments is selected from 2011 to 2015. The accident loss indicators of the comparison sequence of safety investments are selected including the direct accident loss of the first-grade indicator etc. from 2011 to 2015. Common total accident loss algorithm includes the one-to-four direct and indirect ratio method of Heinrich [20] from USA and total loss method of Symonds [21] also from USA which can be calculated by the formula: Total loss $=($ Covered losses $+A \times$ Laying - off injury times

$$
\begin{aligned}
& +B \times \text { Hospitalization injury times } \\
& +C \times \text { Emergency medical times } \\
& +D \times \text { No accident times })
\end{aligned}
$$

In the formula, A, B, C and D separately refer to the average amount of non insurance cost which stands for varieties of different accidents degree. Per capita direct loss of accidents need to be compared with the loss of previous year, so per capita direct loss of accidents was collected as 0.204 yuan /person of 2010, and the indirect loss of decrease loss output

\begin{tabular}{|c|c|c|c|c|c|c|}
\hline $\begin{array}{l}\text { First-grade } \\
\text { indicator }\end{array}$ & $\begin{array}{l}\text { Second-grade } \\
\text { indicator }\end{array}$ & 2011 & 2012 & 2013 & 2014 & 2015 \\
\hline \multirow{5}{*}{$\begin{array}{l}\mathrm{X}_{1} \text { Safety } \\
\text { technical } \\
\text { measures }\end{array}$} & Ventilation system & 45.5 & 47.3 & 44.3 & 55.3 & 57.1 \\
\hline & Protection device & 22.4 & 30.8 & 28.6 & 31.2 & 33.4 \\
\hline & Insurance device & 28.5 & 40.5 & 41.3 & 40.2 & 41.3 \\
\hline & Signal device & 31.1 & 30.9 & 28.4 & 56.5 & 58.1 \\
\hline & Others & 5.9 & 7.7 & 2.5 & 6.6 & 7.5 \\
\hline \multirow{5}{*}{$\begin{array}{l}\mathrm{X}_{2} \text { Industrial } \\
\text { hygiene } \\
\text { measures }\end{array}$} & Dustproof device & 3.1 & 3.4 & 2.8 & 2.8 & 3.2 \\
\hline & $\begin{array}{l}\text { Anti noise and } \\
\text { vibration }\end{array}$ & 1.4 & 1.6 & 1.3 & 1.4 & 1.5 \\
\hline & Gas defense & 1.1 & 1.4 & 1.1 & 1.5 & 1.4 \\
\hline & $\begin{array}{l}\text { Ventilation, } \\
\text { cooling, and cold } \\
\text { proof }\end{array}$ & 2.1 & 2.6 & 1.5 & 1.7 & 1.7 \\
\hline & Others & 1.0 & 0.5 & 0.6 & 0.7 & 1.1 \\
\hline \multirow{6}{*}{$\begin{array}{l}\mathrm{X}_{3} \text { Safety } \\
\text { managemen } \\
\text { t and } \\
\text { training }\end{array}$} & OHSAS operating & 29.8 & 33.5 & 29.7 & 35.4 & 36.6 \\
\hline & $\begin{array}{l}\text { Specific type of } \\
\text { worker training }\end{array}$ & 2.8 & 2.9 & 2.6 & 2.9 & 2.9 \\
\hline & $\begin{array}{l}\text { Three levels of } \\
\text { safety education }\end{array}$ & 0.8 & 0.8 & 0.8 & 0.8 & 0.8 \\
\hline & $\begin{array}{l}\text { Occupational } \\
\text { health examination }\end{array}$ & 22.0 & 27.4 & 24.1 & 28.1 & 28.8 \\
\hline & Emergency rescue & 21.0 & 21.9 & 19.5 & 22.7 & 24.3 \\
\hline & Others & 2.3 & 2.6 & 2.2 & 2.4 & 2.4 \\
\hline \multirow{3}{*}{$\begin{array}{l}\mathrm{X}_{4} \text { Labor } \\
\text { protection } \\
\text { products }\end{array}$} & $\begin{array}{l}\text { Individual } \\
\text { protection }\end{array}$ & 22.4 & 25.5 & 24.1 & 33.2 & 36.7 \\
\hline & Special protection & 37.4 & 40.2 & 40.1 & 51.2 & 52.2 \\
\hline & Others & 7.8 & 11.1 & 6.0 & 4.2 & 6.2 \\
\hline
\end{tabular}
is 4 times of direct loss.

\begin{tabular}{|c|c|c|c|c|c|c|}
\hline \multirow{4}{*}{$\begin{array}{l}\text { Direct } \\
\text { accident loss }\end{array}$} & $\begin{array}{l}\text { Accident property } \\
\text { loss }\end{array}$ & \multicolumn{2}{|c|}{ Accident property } & 10.8 & 14.5 & 10.1 \\
\hline & Accident disposal & 65.3 & 65.7 & 61.4 & 67.9 & 68.9 \\
\hline & $\begin{array}{l}\text { Occupational } \\
\text { disease Prevention }\end{array}$ & 14.3 & 14.5 & 14.2 & 14.6 & 14.9 \\
\hline & Others & 1.2 & 1.3 & 1.1 & 1.3 & 1.4 \\
\hline \multicolumn{2}{|c|}{ Total safety investments } & 288 & 333 & 302 & 379 & 397 \\
\hline \multicolumn{2}{|c|}{ Total number of persons } & 450 & 459 & 410 & 510 & 534 \\
\hline \multicolumn{2}{|c|}{ Gross industrial output value } & 3689 & 3864 & 3216 & 4237 & 4789 \\
\hline \multicolumn{2}{|c|}{ Total production investment } & 867 & 874 & 770 & 890 & 890 \\
\hline \multicolumn{2}{|c|}{ Total accident loss } & 89.3 & 90.4 & 87.5 & 98.3 & 95.3 \\
\hline \multicolumn{2}{|c|}{ Per capita direct loss of accidents } & 0.2 & 0.2 & 0.2 & 0.19 & 0.19 \\
\hline
\end{tabular}

TABLE I: SAFETY INVESTMENTS AND LOSS STATISTICS OF THE MINING

\section{B. Calculating the Safety Benefits of the Mining Industry OHSAS18001}

The key point of calculating safety benefits is to calculate the safety output as shown below [4]:

$B \quad$ (safety output $)=B_{1}$ (decrease loss output $)+$ $B_{2}$ (increment output).

In the formula, $B_{1}$ (decrease loss output) $=\Sigma$ (decrease loss increment $)=$ early loss(before safety measures)-later loss (after safety measures); $B_{2}$ (increment output) = productivity contribution $\times$ total output value.

$Y_{1}$ (safety benefits) can be calculated by the data of Table I as shown in Table II.

TABLE II: SAFETY BENEFITS LIST OF THE MINING INDUSTRY OHSAS18001

\begin{tabular}{lccccc}
\hline \hline & 2011 & 2012 & 2013 & 2014 & 2015 \\
\hline $\begin{array}{l}\text { Decrease loss output } \\
\text { (ten thousand) }\end{array}$ & 13.5 & 2.3 & 4.1 & 5.1 & 10.7 \\
\hline $\begin{array}{l}\text { Increment output } \\
\text { (ten thousand) }\end{array}$ & 1226.8 & 1470.0 & 1259.7 & 1803.3 & 2136.5 \\
\hline $\begin{array}{l}\text { Safety benefits } \\
\text { (yuan/person) }\end{array}$ & 4.3 & 4.4 & 4.2 & 4.8 & 5.4 \\
\hline \hline
\end{tabular}

\section{Safety Investments and Benefits List of the Mining Industry OHSAS18001}

The safety investments and benefits list of the mining industry OHSAS18001 is established according to table1 and 2 as shown in Table III.

TABLE III: SAFETY INVESTMENTS AND BENEFITS LIST OF THE MINING INDUSTRY OHSAS18001

\begin{tabular}{llllll}
\hline \hline DMU & $\mathrm{X}_{1}$ & $\mathrm{X}_{2}$ & $\mathrm{X}_{3}$ & $\mathrm{X}_{4}$ & $\mathrm{X}_{5}$ \\
\hline 2011 & 133.4 & 8.7 & 78.7 & 67.6 & 4.301 \\
2012 & 157.2 & 9.5 & 89.1 & 76.8 & 4.427 \\
2013 & 145.1 & 7.3 & 78.9 & 70.2 & 4.192 \\
2014 & 189.8 & 8.1 & 92.3 & 88.6 & 4.774 \\
2015 & 197.4 & 8.9 & 95.8 & 95.1 & 5.406 \\
\hline \hline
\end{tabular}

D. The Safety Benefits Results Calculating

The safety benefits results are calculated by the software MYDEA of DEA as shown in Table IV. 
TABLE IV: DEA EVALUATION RESULTS OF SAFETY INVESTMENTS AND BENEFITS OF THE MINING INDUSTRY OHSAS18001

\begin{tabular}{|c|c|c|c|c|c|c|c|}
\hline DMU & $\theta$ & $s_{1}^{-}$ & $S_{2}^{-}$ & $S_{3}^{-}$ & $S_{4}^{-}$ & $s_{1}^{+}$ & Efficiency \\
\hline 2011 & 1.0 & 0.0 & 0.0 & 0.0 & 0.0 & 0.0 & $\begin{array}{l}\text { DEA } \\
\text { efficiency }\end{array}$ \\
\hline 2012 & 0.9 & 4.2 & 0.0 & 0.3 & 0.0 & 0.4 & $\begin{array}{l}\text { non DEA } \\
\text { efficiency }\end{array}$ \\
\hline 2013 & 1.0 & 0.0 & 0.0 & 0.0 & 0.0 & 0.0 & $\begin{array}{l}\text { DEA } \\
\text { efficiency }\end{array}$ \\
\hline 2014 & 1.0 & 10.1 & 0.0 & 5.1 & 2.0 & 0.1 & $\begin{array}{l}\text { non DEA } \\
\text { efficiency }\end{array}$ \\
\hline 2015 & 1.0 & 0.0 & 0.0 & 0.0 & 0.0 & 0.0 & $\begin{array}{l}\text { DEA } \\
\text { efficiency }\end{array}$ \\
\hline
\end{tabular}

\section{E. Projection Analysis of $C^{2} R$ Model}

The target value of the improvement work can be achieved with the aid of "projection" analysis" when the decision making unit $\left(D M U_{j 0}\right.$ ) of non DEA efficiency is changed into DEA efficiency. Reference information for the improvement of production and management efficiency in the future can be provided as well.

Theorem 2:

Let $x_{i j 0}^{-}=\theta^{0} \cdot x_{i j 0}-s_{i}^{-0}, y_{r j 0}^{-}=y_{r j 0}+s_{r}^{+0}$. In the formula, $\theta^{0}, s_{i}^{-0}$ and $s_{r}^{+0}$ are the optimal solution for linear programming which corresponds to decision making units $\left(j_{0}\right) .\left(x_{0}, y_{0}\right)$ of the relative efficiency "projection" of DEA which corresponds to $\left(x_{i j 0}^{-}, y_{r j 0}^{-}\right)$is determined to be DEA efficiency. According to the above theorem, the before and after adjustment results of the "projection" analysis" are shown in Table V.

TABLE V: BEFORE AND AFTER ADJUSTMENT RESULTS OF SAFETY BENEFITS "PROJECTION" ANALYSIS" OF THE MINING INDUSTRY OHSAS18001

\begin{tabular}{lllllllllll}
\hline \multirow{2}{*}{ DMU } & \multicolumn{3}{c}{ Before adjustment results } & \multicolumn{6}{c}{ After adjustment results } \\
\cline { 2 - 11 } & $\mathrm{X}_{1}$ & $\mathrm{X}_{2}$ & $\mathrm{X}_{3}$ & $\mathrm{X}_{4}$ & $\mathrm{Y}_{1}$ & $\mathrm{X}_{1}$ & $\mathrm{X}_{2}$ & $\mathrm{X}_{3}$ & $\mathrm{X}_{4}$ & $\mathrm{Y}_{1}$ \\
\hline 2011 & 133.4 & 8.7 & 78.7 & 68 & 4.3 & 133.4 & 8.7 & 78.7 & 67.6 & 4.3 \\
2012 & 157.2 & 9.5 & 89.1 & 77 & 4.43 & 140.0 & 8.7 & 81.4 & 70.5 & 4.5 \\
2013 & 145.1 & 7.3 & 78.9 & 70 & 4.19 & 145.1 & 7.3 & 78.9 & 70.2 & 4.2 \\
2014 & 189.8 & 8.1 & 92.3 & 89 & 4.77 & 174.0 & 7.9 & 84.5 & 83.9 & 4.8 \\
2015 & 197.4 & 8.9 & 95.8 & 95 & 5.41 & 197.4 & 8.9 & 95.8 & 95.1 & 5.4 \\
\hline
\end{tabular}

\section{F. Reference Squence and Comparison Squence Establishing}

As shown in Table VI, the results of DEA "projection analysis" of reference sequence and comparison sequence are shown as below: 0 Safety benefits, 01 Safety technical measures, 02 Industrial hygiene measures, 03 Safety management and training, 04 Labor protection products.

TABLE VI: THE ORIGINAL SEQUENCE OF SAFETY BENEFITS AND INVESTMENT STATISTICS OF THE MINING INDUSTRY OHSAS18001 (UNIT: TEN THOUSAND)

\begin{tabular}{llllll}
\hline \hline Indicators & 2011 & 2012 & 2013 & 2014 & 2015 \\
\hline $\begin{array}{l}\text { 0 Safety benefits } \\
\begin{array}{l}\text { 01 Safety } \\
\text { technical } \\
\text { measures }\end{array}\end{array}$ & 133.4 & 4.5 & 4.2 & 4.8 & 5.4 \\
& & 140.0 & 145.1 & 174.0 & 197.4
\end{tabular}

\begin{tabular}{lccccc}
$\begin{array}{l}02 \text { Industrial } \\
\text { hygiene } \\
\text { measures }\end{array}$ & 8.7 & 8.7 & 7.3 & 7.9 & 8.9 \\
$\begin{array}{l}03 \text { Safety } \\
\text { management } \\
\text { and training }\end{array}$ & 78.7 & 81.4 & 78.9 & 84.5 & 95.8 \\
$\begin{array}{l}04 \text { Labor } \\
\text { protection } \\
\text { products }\end{array}$ & 67.6 & 70.5 & 70.2 & 83.9 & 95.1 \\
\hline \hline
\end{tabular}

\section{G. Initialization Squence Establishing}

As shown in Table VII, according to the formula (2), the initialization value of safety investments and safety benefits of the mining industry OHSAS18001 from 2011 to 2015.

TABLE VII: THE INITIALIZATION VALUE OF SAFETY INVESTMENTS AND SAFETY BENEFITS OF THE MINING INDUSTRY OHSAS18001 (UNIT: TEN THOUSAND)

\begin{tabular}{llllll}
\hline \hline Indicators & 2011 & 2012 & 2013 & 2014 & 2015 \\
\hline $\begin{array}{l}\text { 0 safety benefits } \\
\text { 01 Safety } \\
\text { technical } \\
\text { measures } \\
02 \text { Industrial }\end{array}$ & 1.0 & 1.0 & 1.0 & 1.1 & 1.3 \\
$\begin{array}{l}\text { hygiene } \\
\text { measures } \\
\text { 03 Safety } \\
\text { management } \\
\text { and training }\end{array}$ & 1.0 & 1.0 & 0.8 & 0.9 & 1.0 \\
$\begin{array}{l}\text { 04 Labor } \\
\text { protection } \\
\text { products }\end{array}$ & 1.0 & 1.0 & 1.0 & 1.0 & 1.5 \\
\hline \hline
\end{tabular}

\section{H. Absolute Difference Squence Establishing}

According to the formula (4), safety investments absolute difference sequence of OHSAS18001 from 2011 to 2015 can be obtained as follows:

$$
\begin{aligned}
& \Delta_{01}=(0.000,0.013,0.113,0.193,0.223) ; \\
& \Delta_{02}=(0.000,0.035,0.136,0.208,0.234) ; \\
& \Delta_{03}=(0.000,0.002,0.028,0.038,0.040) ; \\
& \Delta_{04}=(0.000,0.006,0.064,0.130,0.150) .
\end{aligned}
$$$$
\text { Obviously, } \Delta_{\min }=0, \Delta_{\max }=0.234
$$

\section{Relational Coefficient Calculating}

According to the formula (3), let $\rho=0.5$, then the following can be obtained:

$$
\begin{gathered}
\xi_{0 j(k)}=\frac{0+0.5 \times 0.234}{\Delta_{0 i}+0.5 \times 0.234} ; \\
\xi_{01}=\frac{0+0.5 \times 0.234}{\Delta_{01}+0.5 \times 0.234}=(1.000,0.900,0.509,0.377,0.344) ; \\
\xi_{02}=\frac{0+0.5 \times 0.234}{\Delta_{02}+0.5 \times 0.234}=(1.000,0.770,0.463,0.360,0.333) ;
\end{gathered}
$$




$$
\begin{aligned}
& \xi_{03}=\frac{0+0.5 \times 0.234}{\Delta_{03}+0.5 \times 0.234}=(1.000,0.982,0.808,0.360,0.747) ; \\
& \xi_{04}=\frac{0+0.5 \times 0.234}{\Delta_{04}+0.5 \times 0.234}=(1.000,0.955,0.647,0.473,0.438)
\end{aligned}
$$

\section{J. Relation Analyzing}

Let $\omega_{1}=\omega_{2}=\omega_{3}=\omega_{4}=\omega_{5}=1 / 5$, the relation of the comparative indicator $x_{i}$ and reference indicator $x_{0}$ can be obtained as the following:

$$
\begin{gathered}
r_{01}=\frac{1}{5} \sum_{k=1}^{5} \xi_{01}(k)=0.626 ; r_{02}=\frac{1}{5} \sum_{k=1}^{5} \xi_{02}(k)=0.585 ; \\
r_{03}=\frac{1}{5} \sum_{k=1}^{5} \xi_{03}(k)=0.779 ; \\
r_{04}=\frac{1}{5} \sum_{k=1}^{5} \xi_{04}(k)=0.703 . \\
\text { Obviously, } r_{03}>r_{04}>r_{01}>r_{02} .
\end{gathered}
$$

It can be concluded that safety management and training have the highest relation on effective safety benefits of the mining industry, that is, safety management and training have the greatest impact in the safety investments. The next only to that are labor protection, safety technical measures and industrial hygiene measures. In other words, the investment of safety management and training should be strengthened to increase the safety benefits.

\section{CONCLUSION}

The safety benefits of the mining industry are result of the comprehensive function of the internal and external factors. The relative benefits of mining industry are closely related to the national macro regulation, the market situation, the quality of the products and the state of internal management of the mining industry, which are confirmed by the DEA analysis results. The steel market of Hubei Province falling into an all-time low in 2012 resulted in low relative benefits of that year. Additionally, internal reform of the mining industry in 2014 led to low relative benefits of that year.

Although projection analysis can provide managers with the goal of improving the work, this is only theoretical. In the actual work, some indicators value may not be reduced. Therefore, the improvement measures should be made according to the actual situation to achieve transition to DEA efficiency combined with the increase of output.

The purpose of mining occupational health and safety management system is to continuously improve the performance of the enterprise, to guarantee the employee's occupational health and safety, and to ensure rational scientific investment and maximum economic safety benefits. In this paper, the empirical analysis of the mining industry in Southwest Hubei Province confirmed the importance of the safety management and training impact on safety benefits. It also puts forward the people-oriented management appeal to the managers providing a reference for the sustainable and healthy development of mining industry.

\section{ACKNOWLEDGMENT}

Author thanks the statistical personnel of the case study area for their cooperation in the study and leaders of the mine for the guidance.

\section{REFERENCES}

[1] General Administration of quality supervision, inspection and Quarantine of People's Republic of China. National standards of the People's Republic of China, "GB/T28001-2011 Occupational Health and Safety Management Systems Requirements."

[2] C. C. Ma, "The analysis of coal mine safety investment analysis based on grey ralationa," Kunming University of Science and Technology, 2013.

[3] Y. Luo, "Safety economics," Chemical Industry Press, 2004.

[4] Q. Du, "Benefit analysis of safety investment in coal mine based on DEA," Kunming University of Science and Technology, vol. 33, pp. 102-109, 2009.

[5] Y. R. Duan, "Data envelopment analysis-theory and applications," Shanghai Science and Technology Publishing House, vol.21, pp. 78-86, 2006.

[6] W. J. Wu, "Data envelopment analysis and its application," China Statistics Press, 2002.

[7] J. L. Deng. "Control problems of grey systems," Systems \& Control Letters, vol. 01, pp. 288-294, 1982.

[8] A. Bezuglov and G. Comert, "Short-term freeway traffic parameter prediction: application of grey system theory models," Expert Systems with Applications, vol. 62, pp. 284-292, 2016.

[9] Y. Yang and Y. X. Ding, "Continuous fractional-order grey model and electricity prediction research based on the observation error feedback," Energy, vol.115, pp. 722-733, 2016.

[10] X. L. Liu, Blanca Moreno, and Ana Salomé García, "A grey neural network and input-output combined forecasting model," Primary Energy Consumption Forecasts in Spanish Economic Sectors, Energy, vol.115, pp. 1042-1054, 2016. [CrossRef]

[11] F. Lu, X. Liu, and Q. Liu, "The theory of gray relative analysis and it's new research," Journal of Wuhan University of Technology, vol. 22, no. 2, pp. 41-43, 2016.

[12] J. L. Deng, "Basic method of grey system," Huazhong University of Science and Technology Press, 1987.

[13] Y. L. Zhao, S. Y. Wei, and Z. X. Mei, "Grey Euclid relation grade," Journal of Guangxi University, vol.23, no. 2, pp. 10-13,1998.

[14] X. Q. Li, "Research on the computation model of grey interconnect degree," Systems Engineering, vol. 13, pp.58-61, 1995.

[15] S. F. Liu, "Generalized degree of grey incidence: information and systems," Dilian DMU Publishing House, vol.43, pp. 113-116, 1992.

[16] W. X. Tang, "The concept and the computation method of T's correlation degree," Application of Statistics and Management, vol. 14, no. 1, pp. 34-37,1995.

[17] Q. Y. Wang and X. H. Zhao, "The relational analysis of C-mode," Journal of Huazhong University of Science and Technology, vol.27, no.03, pp.75-77, 1999.

[18] Q. Y. Wang, "The grey relational analysis of B-mode," Journal of Huazhong University of Science and Technology, vol.17, no.06, pp.77-82, 1987.

[19] M. J. Lu, M. Zhu, R. Tang, L. G. Ning, H. Li, and L. Wang, "Study on safety assessment modeling in Sijiaying open-pit iron mine," Journal of Hebei Polytechnic University(Natural Science Edition), vol.04, pp.6-11, 2010.

[20] X. M. Wang, X. Li, and Z. H. Yu, "Expend research on the Heinrich rule of Zhejiang Province special equipment accidents," China Public Security Academy Edition, vol.03, pp.16-20, 2014.

[21] Economic Loss Estimation Method for Safety Economics. Available online: http://www.docin.com/p-506752729.html

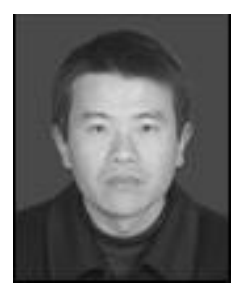

Jiangdong Bao is currently working toward the Ph.D degree at Centre of Advanced Mining and Metallurgy, CAMM, Department of Human Work Science, Luleå University of Technology, and Research Center for Environment and Health, Zhongnan University of Economics and Law for another Ph.D degree. His current research interests include Quality, Environment and Occupational Health and Safety Management System (that is, Standardization Engineering). 


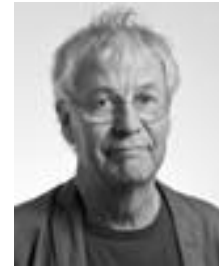

Jan Johansson is a professor of the Department of Business Administration, Technology and Social Sciences, Luleå University of Technology. He is also leading a big division in Industrial Work Environment. His publications achieve more than 200. And his current research interests include Industrial Work Environment, etc.

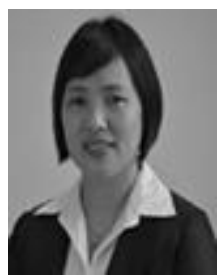

Jingdong Zhang is a head of School of Information and Safety Engineering, Zhongnan University of Economics and Law. Her publications achieve more than 200 as a leading professor. And her current research interests include environmental safety management, environmental quality and safety assessment, occupational health engineering and management, etc. 